pero nos da la pista de que quizás sea el Camino de Santiago la vía por la que pudo llegar, al ser Estella además un hito importante de esa ruta de peregrinación.

Si el camino desde su lugar de producción hasta Estella no está claro, lo está mucho más el que realizó desde Estella a Nueva York. A principios del siglo XX, aprovechando la falta de medios legales para evitarlo y dentro de unas circunstancias bastante propicias a las ventas de bienes muebles eclesiásticos, fue vendida por la parroquia estellesa y pasó a formar parte de la colección de John Pierpoint Morgan y luego a los fondos del Metropolitan $\mathrm{Mu}$ seum de Nueva York, donde hoy se exhíbe ${ }^{40}$.

EMILIo QuintaniLla MarTíneZ Universidad de Navarra

\title{
MARI RODRÍGUEZ, «MAESTRA DE VIDRIERAS» EN LA CUENCA DEL SIGLO XVI
}

En 1582 el cabildo catedralicio de Cuenca decidió encomendar el cuidado de las vidrieras de su catedral a una mujer, después de haber buscado infructuosamente un maestro durante casi seis años. En efecto, en este año de 1582 la vidriera Mari Rodríguez comenzó a trabajar en la catedral y el canónigo obrero le pagó ocho mil novecientos setenta y ocho maravedíes por «aderezar ... las vidrieras de la yglesia y poner los vidrios y lo demas» ${ }^{1}$.

Mari conocía bien su oficio, había trabajado de forma muy activa con su marido Pedro de Valdivieso ${ }^{2}$ en el taller familiar, como lo reconoció el propio Valdivieso en su testamento cuando dice que en el caso de que su mujer contrajera nuevas nupcias «se le den la mitad de los bienes que yo y ella emos ganado durante el matrimonio» ${ }^{3}$. Cuando Valdivieso murió, Mari se puso al frente del taller y una de las obras que su marido había contratado y que ella se comprometió a realizar, fueron dos vidrieras para la iglesia del monasterio de Monsalud ${ }^{4}$.

40 La píxide ya no estaba en Estella en 1911 (vid. Emilio Quintanilla Martínez, Op. cit., p. 287-288) y en 1914 ya fue exhibida en Nueva York como parte de la Morgan Loan Collection (vid. J. Breck, Op. cit., p. 12.).

1 ADC, Libro de fábrica, 1591-1621, fol. 225.

2 La primera noticia que poseemos sobre Mari Rodríguez data de 1566 y se trata de la siguiente partida de bautismo: «En la ciudad de Cuenca en la perroquia de señor San Miguel oy jueves a veynte y ocho dias del mes de hebrero año de mil y quinientos y sesenta y seis años yo Alonso Portero tiniente de cura de la dicha yglesia batize una niña de Alonso Perez vedriero y de su mujer Angela de Villareal su ligitima mujer que llamaron Maria fue su conpadre de pila Pedro de Valdeyvieso vidriero y aconpañado Juan Lopez calcetero y de capita Mari Rodriguez mujer del dicho Valdeyvieso y aconpañada Rafaela de la Cruz mujer del dicho Juan Lopez». (ADC, Libro de bautismos de San Miguel, 1544-1568). Sabemos que de su matrimonio con Pedro de Valdivieso hubo dos hijas, Mariana y Úrsula.

3 AHPC, Lorenzo Bordallo, 1572 (582), fols. 116v-118.

4 Sepan quantos esta carta de obligación vieren como yo Maria Rodriguez de la Puente viuda mujer que fui de Pedro de Valdibieso vedriero difunto vecino desta noble ciudad de Cuenca como principal deudora e yo Pedro Ruiz barbero vecino desta dicha ciudad como su fiador y principal pagador anbos a dos ... otorgamos e conozemos que por quanto el dicho Pedro de Valdibieso marido de mi la susodicha en su vida se obligo por un conocimiento firmado de su mano de dar hechas e puestas e acabadas dos vedrieras para la iglesia del monasterio de Nuestra Señora de Monsalud las quales dichas dos vedrieras an de ser blancas y las avia de dar fechas 
Tanto su marido como su yerno, conocido también por el mismo nombre de Pedro de Valdivieso, fueron vidrieros de la catedral de Cuenca, el primero desde el año 1557 hasta 1572 y el segundo desde 1573 a 1576 , año en el que abandonó Cuenca para trasladarse a Toledo, en cuya catedral trabajó como vidriero 5 .

Mari tuvo el nombramiento de vidriera de la catedral hasta su muerte ocurrida en $1589^{6}$. En un principio el cabildo se quiso aprovechar de su condición de mujer y en lugar de pagarle el salario estipulado, que en el caso de los vidrieros era de seis mil maravedíes anuales, le obligó a conformarse con tres mil maravedíes «para ayuda a sus necesidades porque tenga cuidado de visitar las vidrieras de la yglesia» ${ }^{7}$. Transcurridos dos años, a finales del año 1584, Mari dio un ultimátum al canónigo obrero; si no le pagaba seis mil maravedíes, que era el salario que habían cobrado su marido y su yerno, dejaría su trabajo y se marcharía a Toledo «con su hierno que la a enbiado a llamar». Alarmado el canónigo llevó este asunto al cabildo que se celebró el 22 de diciembre de ese año de 1584, y habló a los capitulares sobre la pobreza de esta mujer que tenía el encargo de «adobar» las vidrieras de la catedral. Asimismo les informó de cómo Mari le había amenazado con marcharse a Toledo con su familia si no le daban el salario. Los capitulares ante la perspectiva de quedarse sin su maestra vidriera y teniendo en cuenta que «no ay quien haga este oficio en la iglesia», acordaron «asentar el salario de los seis mill maravedies que tenia su marido en cada un año y que le corran desde primero de henero del año venidero de 85 en adelante» ${ }^{8}$.

En 1587 además de los seis mil maravedíes de su salario, Mari, a la que llaman «maestra de vidrieras», recibió también mil ciento noventa maravedíes por «adobar dos bidrieras una en el cabildo y otra en la nave de los Reyes» ${ }^{9}$. Un año más tarde, en 1588, Mari, probablemente obligada por su edad y por la dureza del trabajo, vende sus herramientas al pintor Bartolomé Matarana, el cual, a cambio se comprometió a que «si en algun tienpo le quitaren a la dicha Maria Valdivieso los seys mill maravedies de salario que por el dicho oficio le da la iglesia desta dicha ciudad de Cuenca me obligo de le dar yo la mitad del salario que a mi me dieren en qualquier tiempo por el mismo efeto que a ella se les dan ques el hacer de las dichas vidrieras esto por su vida» ${ }^{10}$. Poco tiempo después (abril de 1589), Mari murió y tras un breve período en el que no hubo maestro vidriero en la catedral ${ }^{11}$, el cabildo nombró a Francisco Matarana, hermano del pintor Bartolomé.

\section{LUZ RoKISKI LÁZARO \\ Universidad Politécnica de Madrid}

y acabadas para en fin del mes de agosto deste presente año de mil quinientos setenta y dos años por prescio de dos reales y medio cada palmo y los dias que se detuviere en asentalla a cinco reales para cada un dia y que el hilo de aranbre de las redes que lo abia de pagar el dicho monesterio de por si e para en quenta de las dichas bedrieras rescibio el dicho Pedro de Valdivieso cuatro maravedies en reales e porque agora nosotros queremos cumplirlo que estaba obligado el dicho Pedro de Valdivieso por tanto ... otorgamos y conozemos que nos obligamos de dar al dicho prior del dicho monesterio o a quien su poder obiere las dichas dos bedrieras buenas de dar e de rezebir ... las quales dichas dos bedrieras nos obligamos de las dar y entregar para el dia de San Andres primero venidero deste presente año de mil quinientos e setenta y dos años ... e porque no se escribir yo la dicha Maria Rodriguez de la Puente lo firmo un testigo que fue fecha y otorgada en Cuenca a dos dias del mes de septiembre año del nascimiento de nuestro Salvador Jesuchristo de mil e quinientos e setenta y dos años. (AHPC, Jerónimo León, 1570-1573 (530), fol. 435).

5 M. ․ Luz Rokiski Lázaro, «Bartolomé Matarana, vidriero», $A E A$, n.․2 238, 1987, p. 230. ACC, Libro de fábrica, $1548-1590$, fols. $165 \mathrm{v}, 173,188$.

6 Salvo cuatro meses que estuvo en Toledo en 1585, Mari se ocupo de las vidrieras de la catedral durante casi cuatro años. $A C C$, Libro de fábrica, 1548-1590, fols. 255v, 274v, 277v, 280, 284.

7 ACC, Libro de fábrica, 1548-1590, fols. 225, 251, 251v.

8 ACC, Actas capitulares, 1584 , fols. $81 \mathrm{v}, 82$.

$9 A C C$, Libro de fábrica, 1548-1590, fol. $278 \mathrm{v}$.

10. M. ${ }^{a}$ Luz Rokiski Lázaro; ar. cit., pp. 229,230; «Noticias sobre el pintor Bartolomé Matarana en Cuenca», Cuenca, n. ${ }^{\circ}$ 31/32, 1988, p. 11.

11 M. Luz Rokiski Lázaro, «Noticias documentales sobre Francisco Matarana, vidriero y pintor», AEA, n.․ 277, 1997, pp. 97-99. 